Print ISSN: 2288-4637 / Online ISSN 2288-4645

doi:10.13106/jafeb.2019.vol6.no3.173

\title{
Data Empowered Insights for Sustainability of Korean MNEs*
}

\author{
Young-Eun PARK ${ }^{1}$
}

Received: June 06, 2019 Revised: June 12, 2019 Accepted: July 13, 2019

\begin{abstract}
This study aims to utilize big data contents of news and social media for developing a corporate strategy of multinational enterprises and their global decision-making through the data mining technique, especially text mining. In this paper, the data of 2 news media (BBC and $\mathrm{CNN}$ ) and 2 social media (Facebook and Twitter) were collected for the three global leading Korean companies (Samsung, Hyundai Motor Company, and LG) from April, 2018 to April, 2019. The findings of this paper have shown that traditional news media and also modern social media have become devastating tools to extract global trends or phenomena for businesses. Moreover, this presents that a company can adopt a two-track strategy through two different types of media by deriving the key issues or trends from news media channels and also grasping consumers' sentiments, preference or issues of interest such as battery or design from social media. In addition, analyzing the texts of those media and understanding the association rules greatly contribute to the comparison between two different types of media channels to see the difference. Lastly, this provides meaningful and valuable data empowered insights to find a future direction comprehensively and develop a global strategy for sustainability of business.
\end{abstract}

Keywords: Korean Multinational Enterprises, Data mining, News media, Social media, Sustainability.

JEL Classification Code: C53, D10, D70, F23, M10.

\section{Introduction}

The global marketplace provides many opportunities for firms to increase their revenue base and profitability as well. The trade among nations has increased dramatically in recent years and it is estimated that the trade across nations has exceeded the trade within nations by 2015. However, managers face countless challenges and risks when they diversify abroad. Multinational firms or worldwide, global enterprises which own or control production of goods or services in at least one country other than its home country need to know how to overcome various barriers and create more value when expanding into global markets (Dress,

* The author would like to acknowledge Business, Society \& Environment (BSE) Research Lab, Prince Sultan University, Saudi Arabia for their support.

1 First Author and Corresponding Author. Assistant Professor, Management Department, College of Business Administration, Prince Sultan University, in Riyadh, Kingdom of Saudi Arabia. Tel: +966-11-494-8564, Email: ypark@psu.edu.sa

๑ Copyright: Korean Distribution Science Association (KODISA)

This is an Open Access article distributed under the terms of the Creative Commons Atrribution NonCommercial License (https://creativecommons.org/licenses/by-nc/4.0/) which permits unrestricted no commercial use, distribution, and reproduction in any medium, provided the original work is properly cited.
Lumpkin, Eisner, \& McNamara, 2014; Hill, 2015). It is much more complex and difficult to deal with global consumers who have diverse, different and complicated needs and preferences. Accordingly, companies that engage with global consumers, especially, 'Business to Consumer (B to C)' companies which involve a product or service selling directly from a business to a consumer rather than businesses need to be aware of various issues surrounding the company through third parties, and should continuously scan and vigorously monitor consumers' voices (Park, Chaffa, Kim, \& Ko, 2017; Nguyen, 2018; Park \& Alenezi, 2018). Traditionally, news media, and currently social media such as Facebook and Twitter, have become crucial channels to reflect those, and these issues become invaluable factors in showing global trends and phenomena for businesses. Therefore, analyzing the media contents and understanding associate rules through two different types of media channels (traditional media channels, and at the same time, modern channels of social media such as YouTube and Twitter, which are global real-time platforms) will lead to find and predict key issues, and then it will create steady communication and empathy with consumers, greatly contributing to understanding consumer behavior 
and their responses (Chong, 2015; Lee, Becker, \& Potluri, 2016; Han, Kim, \& Lee, 2017). Especially, data mining, big data, and application of social media are considered as a fertile and trendy field for researchers. Data mining is the process of discovering insightful, gripping, and novel patterns, as well as descriptive, understandable, and predictive models from large-scale data (Zaki \& Meira, 2014). Using this method, it has been possible to connect business world with the proof of news or social media to test the relationship between media channels and its real impact on preference or future prediction of a company (Delen, Walker, \& Kadam, 2005; Sarvestan, Safavi, Parandeh, \& Salehi, 2010; Shweta, 2012; Park et al., 2017; Park \& Alenezi, 2018). Accordingly, a big data is quickly changing the meaning and practice of workplace, and then it affects business strategy to encourage and empower organizations to do data-informed decision. The real value of data-fluent organization, though, is to help drive improvements for the entire organization and make the organization run better because data-driven culture enables innovation and empowerment in an organization (Amigobulls, 2015; Lee et al., 2016; Becker \& Lee, 2019).

Despite many possibilities and benefits of applying data mining techniques to business, to date, there have been very few cases that have been useful practically in business. That is, it has been limited to being used as a key tool for corporate strategy and decision making in business (Delen, Walker, \& Kadam, 2005; Sarvestan, Safavi, Parandeh, \& Salehi, 2010; Shweta, 2012; Amigobulls, 2015; Park et al., 2017; Park \& Alenezi, 2018). Moreover, many studies have been conducted using big data such as news articles and social media comments separately. In other words, research on traditional news article analysis and modern social media analysis has been studied individually, accordingly, there have been few studies comparing the results between them. Additionally, it has been very difficult to manually analyze large-scale unstructured data, such as news articles and social media comments. Since the amount, period, and format of data are too large compared to existing data, it is difficult to collect, store, search and analyze 'big data' by conventional methods. But now we can analyze large-scale unstructured data scientifically and systematically through text mining techniques and tools.

Based on the limitations of existing studies, this research aims to utilize big data contents of traditional news media and modern social media for developing a corporate strategy and global decision-making for sustainability of business. This study will show the possibility of using a dual track strategy in terms of enterprise and consumer by comparing traditional media issues and consumer concerns. In conclusion, this study can provide a basis for establishing a strategy through future forecasting of global corporations and generate important insights for global decision-making for sustainable management of companies and also yield meaningful implications. Accordingly, this study will support existing researches academically and also give us a valuable significance practically.

\section{Literature Review}

\subsection{Globalization of Korean Enterprises}

Doing business internationally is considerably more difficult and challenging than doing business in the home country because each country differs in many ways. It conveys the obstacles to success are much higher and complicated in other countries than in the home country. Each country has incomparable business environments politically, economically, legally, socially and culturally (Hill, 2014; Dress et al., 2014; William, James, \& Susan. 2016). Considering that countries diverge with regard to their political, legal, economic, social and cultural systems under its distinctive environments, existing studies in International Business have presented it is much more risky and demanding to establish and manage a business for global company in the host markets without some apparent competitive edge due to liability of foreignness in the host country which can be described as additional costs socially and economically firms face when they do business in foreign markets (Dunning, 1981; 1998; Kogut \& Singh, 1990; Barney \& Hesterly, 2013; Hill, 2014; Park, 2017; Park et al., 2017; Park, 2018). Nonetheless, many large, even small and medium-sized companies are making a lot of effort to go abroad and offset the shortcomings by developing ownership advantages. For reasons, the global market offers lots of opportunities and advantages as well for firms to increase their revenue base and profitability (Hill, 2014).

Accordingly, Korean multinational enterprises (hereafter, MNEs) actively promote overseas expansion, and the globalization is intensifying through foreign direct investment since 2007. As a result, the amount of foreign direct investment became more than $\$ 20$ billion. Foreign trade is traditionally led by the past, now overseas investment through foreign direct investment. It is rapidly changing the transition from the era of trade to the era of direct investment in foreign markets and leads to open up a new horizon. Foreign direct investment of Korean companies became a trade surplus in the mid-1980s, and then it is possible to say that the foreign direct investment of the enterprise has become full-scale in the early 90's even though there has been concern that the domestic economy 
will become hollow if direct investment soars dramatically with wage increases, won appreciation and corporate bandwagon investment in Korea (Lee, 2010). However, even during this period, the ratio of foreign direct investment to GDP does not exceed $1 \%$ respectively. Foreign direct investment remained around US \$ 5 billion after the financial crisis in 1997, and $\$ 22.4$ billion in 2007. In 2013, it reached $\$ 29.5$ billion. This foreign direct investment is more than $2 \%$ of GDP level, which has not been seen in the past. As a result, Korean companies' overseas production and sales are rapidly increasing. According to the statistics of the Export-Import Bank of Korea, exports nearly became triple from $\$ 197.2$ billion to $\$ 553.5$ billion in 2012 . The global management of Korean companies, which have expanded rapidly since 2006 , is growing day by day. This strategy of those companies directly affects the competitiveness of the company, foreign trade of Korean economy and future Korean economy as well. In the sense that Korean economy maintains an outward-oriented attitude, it seems to be a positive phenomenon. Moreover, in 2018, the Ministry of Commerce, Industry and Energy (MOCIE) announced in 2019 that exports amounted to US $\$ 605.47$ billion (5.5\%) and imports reached US $\$ 534.99$ billion (11.8\%) for the 10th consecutive year, companies recorded a profit of $\$ 70.49$ billion. It is a very surprising result considering that only 10 countries including Korea have recorded trade surplus. At the same time, four countries (Korea, China, Germany, and the Netherlands) including Korea have achieved 1 trillion dollars in trade. With this positive stimulus, it cannot be denied that leading companies in Korea such as Samsung, Hyundai Motor Company, and LG have made a big contribution to such a tremendous result. Hence, this study focuses on the global presences and activities of three Korean leading multinational enterprises.

First, Samsung which means 'tri-star' in English is a South Korean multinational conglomerate headquartered in Seoul, Korea and it is the largest one called 'Korean chaebol' meaning business conglomerate. It incorporates numerous affiliated businesses; most of them have the united Samsung brand. Samsung was established by Lee, Byungchul in 1938 as a trading company. Over the next three decades, the Samsung group expanded the business into several sectors including textiles, insurance, food processing, securities, and retail. Then, Samsung entered the electronics industry in the late 1960s and even the construction and shipbuilding industries in the mid-1970s. These areas would drive its subsequent growth and huge success. Following Samsung's founder, Lee's death in 1987, Samsung was isolated into four business groups Samsung Group, Shinsegae Group, CJ Group, and Hansol Group. Since 1990, Samsung has increasingly globalized its activities, in particular, electronics, its mobile phones and semiconductors have become its most crucial and pivotal source of income and brand value worldwide. Accordingly, as of the most valuable brands worldwide 2019, Samsung has the 5th highest global brand value following Amazon, Apple, Google and Microsoft (statista, 2019). Samsung has a mighty influence on South Korea's economic development, politics, media and culture and has been a major powerhouses and driving force behind the 'Miracle on the Han River' referring to the rapid economic growth transformed from a developing to a developed country in South Korea following the Korean War from 1950 to 1953 due to the fact that its affiliate companies produce around a fifth of South Korea's total exports. Moreover, Samsung's revenue was equal to $17 \%$ of South Korea's $\$ 1,082$ billion GDP.

The Hyundai Motor Company, commonly known as Hyundai Motors is also a South Korean multinational automotive manufacturer headquartered in Seoul, Korea, as the third largest vehicle manufacturer in the world. The company was founded in 1967 and, along with its 32.8\% owned subsidiary, Kia Motors, and its $100 \%$ owned luxury subsidiary Genesis Motor, altogether consist of the Hyundai Motor Group. Hyundai operates the world's largest amalgamated automobile manufacturing facility in Ulsan, South Korea which has an annual production capacity of 1.6 million units. Hyundai vehicles are sold in 193 countries through some 5,000 dealerships and showrooms. Moreover, the company employs about 75,000 people worldwide. The founder of Hyundai, Chung, Ju-Yung established the Hyundai Engineering and Construction Company in 1947. Hyundai Motor Company was later created in 1967. Hyundai began to sell cars in the United States in 1986, and the Excel was nominated as 'Best Product \#10' by Fortune magazine, largely by virtue of its affordability. Hyundai began to produce several models with its own technology in 1988, kicking off with the midsize Sonata. Hyundai began to overhaul its image with the intention of establishing itself as a world-class brand. The founder, Chung, Ju-Yung transferred leadership of Hyundai Motor to his son, Chung, Mong-Koo, in 1999. Hyundai's parent company, Hyundai Motor Group, invested heavily in the quality, design, manufacturing, and long-term research of its innovative and eco-friendly vehicles. Hyundai is now one of the top 100 most valuable brands worldwide.

Lastly, LG Corporation, formerly Lucky-Goldstar, is also a South Korean multinational conglomerate corporation. It is the fourth-largest chaebol in South Korea. LG makes electronics, chemicals, and telecom products, and then operates several subsidiaries such as LG Electronics, Zenith, LG Display, LG Uplus, LG Innotek and LG Chem in over 80 countries. LG established Chemical Industrial Corp. as Lucky in 1947. In 1952, it became the first South Korean 
company to enter the plastics industry. As the company expanded its plastics business, it established GoldStar Co. Ltd. (currently LG Electronics) in 1958. Both companies Lucky and GoldStar merged and formed Lucky-Goldstar in 1983. Finally, Koo, Bon-moo renamed the company to LG in 1995. The company also associates the letters LG with the company's slogan "Life's Good". Currently, LG is considered as one of the leading consumer electronics companies including health care sector with around $\$ 58$ billion in global revenue.

Remarkably, by reason of the global development of those three companies, it is clear that all business environments go beyond the familiar domestic and local markets even though it is a great adventure. At this point, it is necessary to grasp the current situation of corporate globalization and to examine the global penetration of Korean leading companies in order to forecast a better future based on various big data through traditional and modern media channels, providing academic and practical implications.

\subsection{Decision-Making based on big data using Data Mining Techniques}

Traditionally, 20th century reporting style as a mainstream media was the important source of finding the news information or essential stories and then, distributing, delivering it to the public through newspapers such as BBC, $\mathrm{CNN}, \mathrm{ABC}$, radio and TV. The public trusted journalists and journalists reported pertinent information of the day (Skoler, 2009; Rottwilm. 2014). Without a doubt, traditional news media channels are the most powerful and influential tools as a mainstream media which is used almost every day in public discourse. (Newman, 2009; Squires, 2016). However, the ways humans spread information have been changed radically. Technology advanced the methods or means of information sharing (Squires, 2016). Hence, user-generated contents of picture, video scoops or any comments through social media such as Facebook, twitter, Instagram or YouTube regularly have replaced the classical, conventional journalism. Those lead television bulletins and the front pages of newspapers, whilst a new category of opinionated blogging is redefining the edge of journalism itself (Newman, 2009). Like this, social media became one of most overpowering tools to affect traditional media and it has been proved practically for changing the impact or perception of a person, product or even business by predicting or deriving the sentiments. Internet searches' patterns and terms also reveal that how people discern or think about the product, people or business (Park et al., 2017; Park \& Alenezi, 2018). As a consequence, most global leading companies have opened their accounts on the social media and showed these on their companies' websites to manage company reputation and profile with social media (Lee et al., 2016; Becker \& Lee, 2019).

Especially, since 2000, diverse researches have been conducted to identify key words or issues in news article and user needs in social media using data mining tools that can analyze big data evolved. Data mining has been used primarily for use in the medical field to predict the survival rate of cancer patients, and now in a variety of public sectors, for example, forecasting of electricity demand or stock price (Sarvestan, Safavi, Parandeh, \& Salehi, 2010; Shweta, 2012; Amigobulls, 2015). In addition, researches are being actively carried out in various countries around the world to analyze and monitor global trends by detecting disease and disaster related information from various web and social media in terms of public interest (UN Agency, 2009; Han, Kamber, \& Pei, 2012; Lee et al., 2013; Gartner, 2015). However, there is an explosion in interest in big data analysis technology due to the rapid increase in demand for information analysis and integration on a large amount of social media information generated in real time and various types of data information that have been established. In particular, in the field of business informatics, technologies such as information reporting, analysis, monitoring, and forecasting using big data information are utilized for business management decisions such as corporate brand and product's design, marketing and corporate strategic planning for future. Business intelligence was mainly focused on monitoring specific brands, user feedback analysis, network analysis based on marketing and decision making. Ultimately, the key to big data analytics technology will be analysis and forecasting of key events or issues across the enterprise, based on information analysis of large volumes of data. It is certainly the purpose of business intelligence to utilize it for optimal decision making based on this. In response to this trend, various analytical tools for analyzing big data such as news article, social media, google trends and others have begun to be developed worldwide (Lee, Hur, Oh, Kim, Ryu, \& Kim, 2013; Park \& Alenezi, 2018).

\subsection{Proposed framework of this study}

Aiming to analyze the key issues and main trends of Korean MNEs in the world markets, the author took on a data-driven method set up on data mining technique, particularly, text mining without a theoretical framework. Exploratory data analysis aims to explore the numeric and categorical attributes of the data individually or jointly to extract key characteristics of the data sample via statistics that give information about the frequency, centrality, 
dispersion, and so on. This enables one to extract important topological attributes that give insights into the structure and models of networks and graphs (Zaki \& Meira, 2014).

In this paper, the collected data represents unstructured texts composed of a chronological sequence or history of observations on news articles and posts/comments of social media by several channels associated to public pages of Samsung, Hyundai Motor Company, and LG. Identifying key trends or issues or predicting future trends of Korean multinationals for global marketplaces can anticipate future consumer behavior so as to increase the success rate and optimize profitability of multinational enterprises worldwide. The complete research framework is shown in following diagram. The figure 1 shows a framework that can collect data from various sources such as news media, social media, search engines like Google Trends and others such as stock and financial reports. Based on this holistic framework, the author focuses on extracting dataset only from news and social media channels as a main research target below.

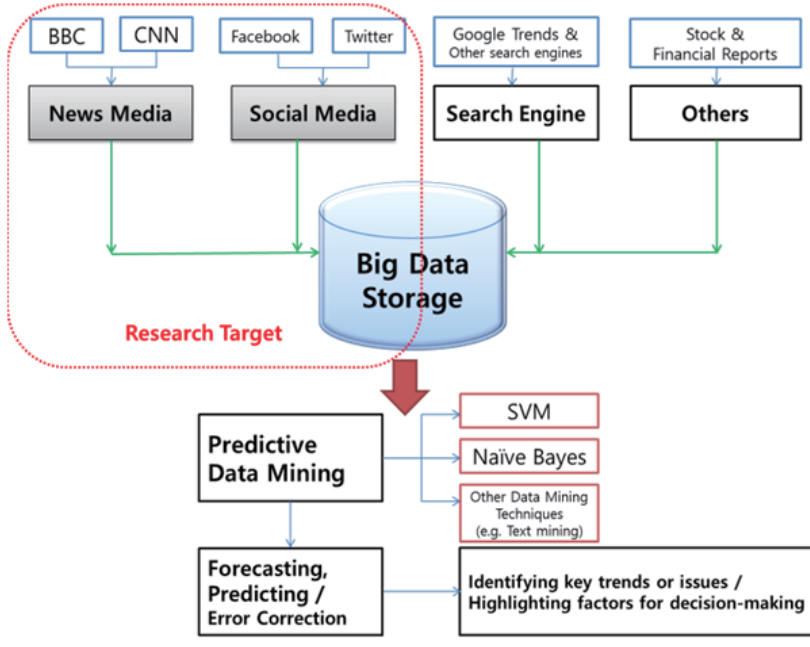

Figure 1: The proposed framework of this study

\section{Data and Methodology}

\subsection{Data Selection}

In this paper, the data was collected from the different sources of 2 news media (BBC and CNN) and 2 social media channels (Facebook and Twitter) for three global Korean companies (Samsung, Hyundai Motor Company, and LG) during the period of April, 2018 to April, 2019. The data mining programs named 'RapidMiner Studio 9.2.1' and 'NetMiner 4 (version 4.4.3. provided Cyram Inc.)' were used to detect and predict key issues and trends of Korean multinational enterprises selected in the world marketplaces. The selection of companies in this study was made using the following 4 criteria.

a) Must be in Top 10 category for ranking published by Fair Trade Commission in Korea (based on total assets).

b) Must be recognized by Korean Investors Services (also the equivalency of Standard \& Poor's global ratings and Moody's).

c) Must be in Fortune Global 500 list (of 2018). The popularity can be found locally and internationally in global markets.

d) Must have their presence on the news article and social media as well.

Thus, among them, three Korean leading companies were selected that are shown in Table 1.

Table 1: The list of companies selected along with selection criteria fulfillment

\begin{tabular}{|c|c|c|c|c|c|}
\hline $\begin{array}{c}\text { Company } \\
\text { Name }\end{array}$ & $\begin{array}{c}\text { Worldwide } \\
\text { Presence } \\
\text { (B to C) }\end{array}$ & $\begin{array}{c}\text { Top10 } \\
\text { Ranked }\end{array}$ & $\begin{array}{c}\text { Korean } \\
\text { Investors } \\
\text { Services }\end{array}$ & $\begin{array}{c}\text { Fortune } \\
\text { Global } \\
500 \text { list } \\
\text { of 2018 }\end{array}$ & $\begin{array}{c}\text { Social } \\
\text { Media } \\
\text { Presence }\end{array}$ \\
\hline Samsung & $\checkmark$ & $\checkmark$ & $\checkmark$ & $\checkmark$ & $\checkmark$ \\
\hline $\begin{array}{c}\text { Hyundai } \\
\text { Motor } \\
\text { Company }\end{array}$ & $\checkmark$ & $\checkmark$ & $\checkmark$ & $\checkmark$ & $\checkmark$ \\
\hline LG & $\checkmark$ & $\checkmark$ & $\checkmark$ & $\checkmark$ & $\checkmark$ \\
\hline
\end{tabular}

In addition, the selection criteria of the news media are as follows. Through the surveys conducted by the Pew Research Center (2014), two of the TOP 10 media, which are the most reliable and comprehensive with major audiences as the major media players, BBC and CNN were selected. In addition, Facebook and Twitter as two main sources of social media were selected considering that usage index is high based on the number of followers and the data was collected in multiple pages of social media in this study. Based on that, the top frequency terms were extracted through descriptive statistics, and then the association rules based on their support and reliability. This shows that the core issues selected with a high score are more meaningful than simply the term frequency through association analysis.

\subsection{Data Cleaning and Data Refinement}

Most often, data involves unnecessary or ambiguous contents. In particular, social media data often includes meaningless texts such as colon, symbols, emoticons and slang frequently used other than the subject of analysis and, 
there are many consonant and vowel data, spelling errors as well. Thus, it is essential to filter the data through preprocessing for the data cleaning and refinement performed on the data sets used for this research to make it more meaningful for analysis (Chong, 2015; Balan \& Rege, 2017; Han, Kim, \& Lee, 2017). For this, worthless characters that are not defined such as letters, special symbols, homepage addresses, or the like consisting of vowels or consonants are removed through the filtering process in advance. In the pre-processed text, word tab is added to the result area. The Word tab provides such information as a list of words, frequency of use, part of speech which are to be extracted from the text contents according to the text process settings. After refining the data, the quality of the data for analysis is improved overall.

\section{Results}

This study aims to analyze texts of global news articles and social media posts/comments of Korean multinational corporations. To this end, totally, 137 news articles and 49,560 posts/comments during the period of April, 2018 to April, 2019 were collected and analyzed. Only main news articles to cover the issues of each company directly were selected and number of social media posts/comments, tweets is limited due to the possible number of nodes in the program for analysis. The results of data collection for each channel are as follows.

Table 2: Number of articles and comments per channel used in the analysis

\begin{tabular}{|c|c|c|c|c|}
\hline & \multicolumn{2}{|c|}{$\begin{array}{c}\text { Number of } \\
\text { News articles } \\
\text { used for } \\
\text { analysis }\end{array}$} & \multicolumn{2}{|c|}{$\begin{array}{c}\text { Number of } \\
\text { posts/comments/tweets used } \\
\text { for analysis }\end{array}$} \\
\hline Company & BBC & CNN & $\begin{array}{c}\text { Facebook } \\
\text { (Followers) }\end{array}$ & $\begin{array}{c}\text { Twitter } \\
\text { (Followers) }\end{array}$ \\
\hline Samsung & 31 & 40 & $7201(49.7 \mathrm{M})$ & $\begin{array}{c}16791 \\
(418 \mathrm{~K})\end{array}$ \\
\hline Hyundai & 23 & 16 & $2639(4.7 \mathrm{M})$ & $\begin{array}{c}8107 \\
(48.2 \mathrm{~K})\end{array}$ \\
\hline LG & 12 & 15 & $4531(12.8 \mathrm{M})$ & $\begin{array}{c}10291 \\
(98.5 \mathrm{~K})\end{array}$ \\
\hline Total & 66 & 71 & 14,371 & 35,189 \\
\hline
\end{tabular}

Note: The number of followers was calculated in one or multiple pages (Unit: K- thousand, M- million)

The frequency of media with regard to each Korean MNE can be analyzed and then, extracted the top 10 rankedterms. Based on that, the author visualizes the text by creating a word cloud. One best way to see obvious patterns or keywords in text data is to generate word clouds. The analysis results are as follows.

Table 3: Term Frequency on Samsung

\begin{tabular}{|c|c|c|c|c|c|c|c|c|}
\hline \multirow{3}{*}{ No. } & \multicolumn{4}{|c|}{ News Media Source } & \multicolumn{4}{|c|}{ Social Media Source } \\
\hline & \multicolumn{2}{|c|}{ BBC } & \multicolumn{2}{|c|}{ CNN } & \multicolumn{2}{|c|}{ Facebook } & \multicolumn{2}{|c|}{ Twitter } \\
\hline & Word & $\begin{array}{c}\text { Frequency } \\
\text { (Portion) }\end{array}$ & Word & $\begin{array}{l}\text { Frequency } \\
\text { (Portion) }\end{array}$ & Word & $\begin{array}{c}\text { Frequency } \\
\text { (Portion) }\end{array}$ & Word & $\begin{array}{c}\text { Frequency } \\
\text { (Portion) }\end{array}$ \\
\hline 1 & Galaxy & $\begin{array}{c}533 \\
(0.242) \\
\end{array}$ & Galaxy & $\begin{array}{c}651 \\
(0.454) \\
\end{array}$ & innovation & $\begin{array}{c}8210 \\
(0.218) \\
\end{array}$ & Exclusive & $\begin{array}{l}10700 \\
(0.218) \\
\end{array}$ \\
\hline 2 & smartphone & $\begin{array}{c}485 \\
(0.220) \\
\end{array}$ & foldable & $\begin{array}{c}205 \\
(0.143)\end{array}$ & best & $\begin{array}{c}6400 \\
(0.170)\end{array}$ & Incredible & $\begin{array}{c}7200 \\
(0.147)\end{array}$ \\
\hline 3 & fold/folding & $\begin{array}{c}374 \\
(0.170)\end{array}$ & smartphone & $\begin{array}{c}110 \\
(0.077)\end{array}$ & awesome & $\begin{array}{c}4320 \\
(0.115)\end{array}$ & favorite & $\begin{array}{c}6170 \\
(0.126)\end{array}$ \\
\hline 4 & launch & $\begin{array}{c}260 \\
(0.118)\end{array}$ & new & $\begin{array}{c}99 \\
(0.069)\end{array}$ & Galaxy & $\begin{array}{c}4222 \\
(0.112)\end{array}$ & battery & $\begin{array}{c}5670 \\
(0.116)\end{array}$ \\
\hline 5 & profit & $\begin{array}{c}176 \\
(0.080)\end{array}$ & note & $\begin{array}{c}97 \\
(0.068)\end{array}$ & Apple & $\begin{array}{c}3207 \\
(0.085)\end{array}$ & US & $\begin{array}{c}4480 \\
(0.091)\end{array}$ \\
\hline 6 & $5 G$ & $\begin{array}{c}159 \\
(0.072)\end{array}$ & breaking & $\begin{array}{c}78 \\
(0.054)\end{array}$ & $5 G$ & $\begin{array}{c}3020 \\
(0.080)\end{array}$ & fancy & $\begin{array}{c}4407 \\
(0.090)\end{array}$ \\
\hline 7 & chip & $\begin{array}{c}79 \\
(0.036)\end{array}$ & profit & $\begin{array}{c}60 \\
(0.042)\end{array}$ & love & $\begin{array}{c}2570 \\
(0.068)\end{array}$ & design & $\begin{array}{c}3240 \\
(0.066)\end{array}$ \\
\hline 8 & worker & $\begin{array}{c}57 \\
(0.026)\end{array}$ & $5 G$ & $\begin{array}{c}53 \\
(0.037)\end{array}$ & customer & $\begin{array}{c}2338 \\
(0.062)\end{array}$ & Apple & $\begin{array}{c}3117 \\
(0.064)\end{array}$ \\
\hline 9 & patent & $\begin{array}{c}42 \\
(0.019)\end{array}$ & US & $\begin{array}{c}42 \\
(0.029)\end{array}$ & feature & $\begin{array}{c}1750 \\
(0.047)\end{array}$ & technology & $\begin{array}{c}2070 \\
(0.042)\end{array}$ \\
\hline 10 & battle & $\begin{array}{c}37 \\
(0.017)\end{array}$ & China & $\begin{array}{c}39 \\
(0.027)\end{array}$ & poor service & $\begin{array}{c}1560 \\
(0.041)\end{array}$ & intelligent & $\begin{array}{c}2009 \\
(0.040)\end{array}$ \\
\hline
\end{tabular}

Note: This result excludes the word of each company name as a keyword. 
The result shows the main top keywords of the news channel are similar (top 3 key words: Galaxy, Smartphone and folding), but the approaches of news reporting are different to deliver news issues or stories. In other words, it can be seen that the perspectives dealing with companies differ from one news channel to another. For example, the BBC is approaching from a negative point of view, primarily handling with hostile issues about Samsung's legal issues against Apple and Huawei even patent disputes, Samsung's union issues, employees' demonstration against Samsung for compensation. It seems like news on the subject of Samsung are more biased and unjust. Rather than delivering an objective view of information about Samsung products, it focuses on product defects and carries dissenting, opposing views with a little bit subjective standpoint. This perspective of the news media can have a significant impact on product sales and revenue by giving consumers a bad perception or impression before the product is officially released. However, CNN deals with Samsung's product issues, technical information, competition between US company (Apple) and China (Huawei), etc. from a more objective perspective. On the other hand, the main keywords of the social media are consumers' emotions or sentiments (e.g. best, awesome, exclusive and incredible) and their concerns like battery, design, etc.. The result has shown the product itself expressed satisfactory, but the feeling of customer service was very negative.

Next, the analysis results of Hyundai Motor are similar to those of Samsung. In the BBC, negative news stories or viewpoints such as recall, dismissal, and stability issues were emerged while CNN is comparing Hyundai's car models from an objective perspective (such as sedans vs. SUVs, luxury cars or trucks, etc.). In the case of social media, consumers' emotions and feelings about the ride quality and technological power of Hyundai Motors were mainly mentioned as keywords. On Twitter, consumers' discoveries and feelings about the activities of social responsibility and contribution through a donation of Hyundai Motor Foundation have emerged as below.
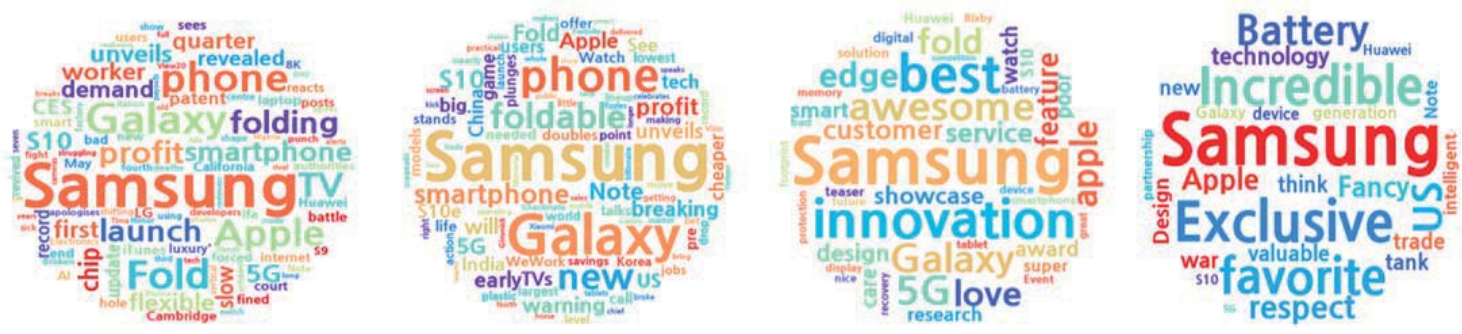

Figure 2: Word Cloud on Samsung (BBC vs. CNN vs. Facebook vs. Twitter)

Table 4: Term Frequency on Hyundai Motor Company

\begin{tabular}{|c|c|c|c|c|c|c|c|c|}
\hline \multirow{3}{*}{ No. } & \multicolumn{4}{|c|}{ News Media Source } & \multicolumn{4}{|c|}{ Social Media Source } \\
\hline & \multicolumn{2}{|c|}{ BBC } & \multicolumn{2}{|c|}{ CNN } & \multicolumn{2}{|c|}{ Facebook } & \multicolumn{2}{|c|}{ Twitter } \\
\hline & Word & $\begin{array}{l}\text { Frequency } \\
\text { (Portion) }\end{array}$ & Word & $\begin{array}{c}\text { Frequency } \\
\text { (Portion) }\end{array}$ & Word & $\begin{array}{c}\text { Frequency } \\
\text { (Portion) }\end{array}$ & Word & $\begin{array}{c}\text { Frequency } \\
\text { (Portion) }\end{array}$ \\
\hline 1 & Kia & $\begin{array}{c}301 \\
(0.435)\end{array}$ & year & $\begin{array}{c}85 \\
(0.195)\end{array}$ & show & $\begin{array}{c}2670 \\
(0.245)\end{array}$ & intelligent & $\begin{array}{c}4750 \\
(0.370)\end{array}$ \\
\hline 2 & Lee & $\begin{array}{c}90 \\
(0.130) \\
\end{array}$ & car & $\begin{array}{c}78 \\
(0.179) \\
\end{array}$ & comfort & $\begin{array}{c}1890 \\
(0.173)\end{array}$ & South & $\begin{array}{c}2408 \\
(0.187)\end{array}$ \\
\hline 3 & year & $\begin{array}{c}85 \\
(0.123) \\
\end{array}$ & truck & $\begin{array}{c}66 \\
(0.152) \\
\end{array}$ & auto & $\begin{array}{c}1765 \\
(0.162) \\
\end{array}$ & Korea & $\begin{array}{c}2318 \\
(0.180) \\
\end{array}$ \\
\hline 4 & vehicle & $\begin{array}{c}68 \\
(0.098) \\
\end{array}$ & luxury & $\begin{array}{c}59 \\
(0.136)\end{array}$ & innovation & $\begin{array}{c}1689 \\
(0.155)\end{array}$ & auto & $\begin{array}{c}1567 \\
(0.122)\end{array}$ \\
\hline 5 & recall & $\begin{array}{c}52 \\
(0.075)\end{array}$ & award & $\begin{array}{c}42 \\
(0.097)\end{array}$ & happy & $\begin{array}{c}821 \\
(0.075)\end{array}$ & donation & $\begin{array}{c}524 \\
(0.040)\end{array}$ \\
\hline 6 & fire & $\begin{array}{c}36 \\
(0.052)\end{array}$ & Genesis & $\begin{array}{c}31 \\
(0.071)\end{array}$ & favorite & $\begin{array}{c}765 \\
(0.070)\end{array}$ & Korean & $\begin{array}{c}427 \\
(0.033)\end{array}$ \\
\hline 7 & safety & $\begin{array}{c}24 \\
(0.035)\end{array}$ & auto & $\begin{array}{c}28 \\
(0.064)\end{array}$ & safest & $\begin{array}{c}448 \\
(0.041)\end{array}$ & $\begin{array}{c}\text { manufacturi } \\
\text { ng }\end{array}$ & $\begin{array}{c}365 \\
(0.028) \\
\end{array}$ \\
\hline 8 & $\mathrm{FC}$ & $\begin{array}{c}15 \\
(0.022) \\
\end{array}$ & sedan & $\begin{array}{c}17 \\
(0.040) \\
\end{array}$ & ultimate & $\begin{array}{c}364 \\
(0.033) \\
\end{array}$ & tremendous & $\begin{array}{c}289 \\
(0.022) \\
\end{array}$ \\
\hline 9 & Korean & $\begin{array}{c}14 \\
(0.020) \\
\end{array}$ & SUV & $\begin{array}{c}16 \\
(0.037) \\
\end{array}$ & vehicles & $\begin{array}{c}342 \\
(0.031) \\
\end{array}$ & engineers & $\begin{array}{c}165 \\
(0.013) \\
\end{array}$ \\
\hline 10 & investigation & $\begin{array}{c}7 \\
(0.010)\end{array}$ & show & $\begin{array}{c}13 \\
(0.030)\end{array}$ & cheerful & $\begin{array}{c}153 \\
(0.014)\end{array}$ & enthusiast & $\begin{array}{c}51 \\
(0.004)\end{array}$ \\
\hline
\end{tabular}

Note: This result excludes the word of each company name as a keyword. 
In the case of LG, both news channels are focusing more on LG's other home appliances (e.g. OLED TVs) or premium products (e.g. LG Signature) than smartphones, and are more interested in comparing Samsung rather than other global competitors (Apple and Huawei). On the other hand, the result of social media is also showing positive feelings such as convenience, ideal design and differentiation of LG's household appliances, but the feeling or impression of service to global consumers was very poor like Samsung's case. One unique issue about LG is that global consumers are showing a lot of interest in LG's health care products including beauty products such as cosmetics.
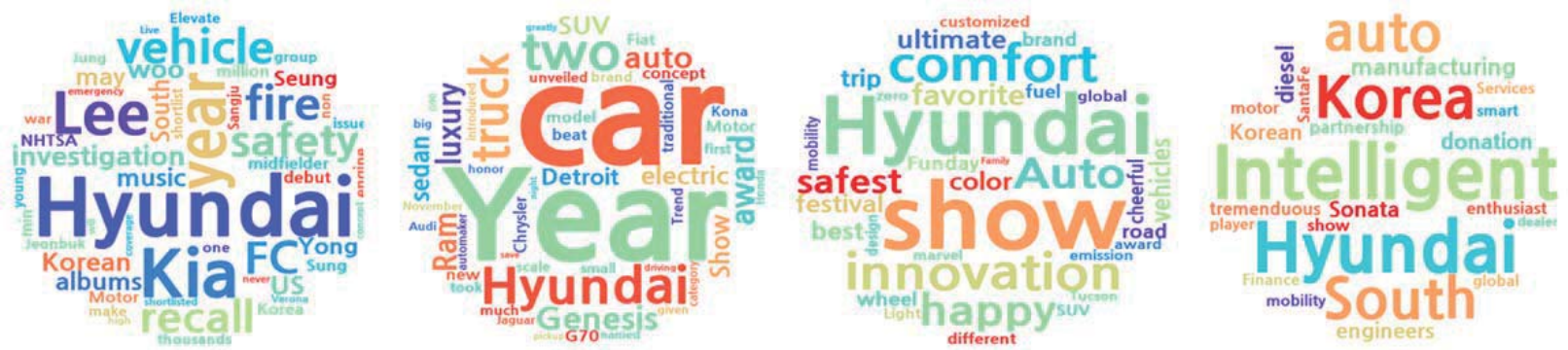

Figure 3: Word Cloud on Hyundai Motor Company (BBC vs. CNN vs. Facebook vs. Twitter)

Table 5: Term Frequency on LG

\begin{tabular}{|c|c|c|c|c|c|c|c|c|}
\hline \multirow{3}{*}{ No. } & \multicolumn{4}{|c|}{ News Media Source } & \multicolumn{4}{|c|}{ Social Media Source } \\
\hline & \multicolumn{2}{|c|}{ BBC } & \multicolumn{2}{|c|}{ CNN } & \multicolumn{2}{|c|}{ Facebook } & \multicolumn{2}{|c|}{ Twitter } \\
\hline & Word & $\begin{array}{l}\text { Frequency } \\
\text { (Portion) }\end{array}$ & Word & $\begin{array}{l}\text { Frequency } \\
\text { (Portion) }\end{array}$ & Word & $\begin{array}{l}\text { Frequency } \\
\text { (Portion) }\end{array}$ & Word & $\begin{array}{c}\text { Frequency } \\
\text { (Portion) }\end{array}$ \\
\hline 1 & OLED & $\begin{array}{c}70 \\
(0.230) \\
\end{array}$ & TV & $\begin{array}{c}383 \\
(0.548) \\
\end{array}$ & TV & $\begin{array}{c}5460 \\
(0.385) \\
\end{array}$ & Health & $\begin{array}{c}3240 \\
(0.340) \\
\end{array}$ \\
\hline 2 & screen & $\begin{array}{c}62 \\
(0.203) \\
\end{array}$ & year & $\begin{array}{c}117 \\
(0.167)\end{array}$ & smart & $\begin{array}{c}3560 \\
(0.251)\end{array}$ & $\begin{array}{c}\text { worst } \\
\text { service }\end{array}$ & $\begin{array}{c}1560 \\
(0.164)\end{array}$ \\
\hline 3 & tech & $\begin{array}{c}50 \\
(0.164) \\
\end{array}$ & screen & $\begin{array}{c}52 \\
(0.074) \\
\end{array}$ & convenient & $\begin{array}{c}1670 \\
(0.118) \\
\end{array}$ & care & $\begin{array}{c}1289 \\
(0.135) \\
\end{array}$ \\
\hline 4 & display & $\begin{array}{c}43 \\
(0.141) \\
\end{array}$ & Electronics & $\begin{array}{c}45 \\
(0.064) \\
\end{array}$ & $\begin{array}{c}\text { differentiate } \\
\mathrm{d}\end{array}$ & $\begin{array}{c}1400 \\
(0.099) \\
\end{array}$ & display & $\begin{array}{c}1165 \\
(0.122)\end{array}$ \\
\hline 5 & CES & $\begin{array}{c}22 \\
(0.072)\end{array}$ & Samsung & $\begin{array}{c}35 \\
(0.050)\end{array}$ & motion & $\begin{array}{c}754 \\
(0.053)\end{array}$ & curved & $\begin{array}{c}721 \\
(0.076)\end{array}$ \\
\hline 6 & set & $\begin{array}{c}16 \\
(0.052)\end{array}$ & OLED & $\begin{array}{c}28 \\
(0.040)\end{array}$ & $\begin{array}{c}\text { responsibilit } \\
y\end{array}$ & $\begin{array}{c}385 \\
(0.027)\end{array}$ & brands & $\begin{array}{c}514 \\
(0.054)\end{array}$ \\
\hline 7 & year & $\begin{array}{c}14 \\
(0.046)\end{array}$ & display & $\begin{array}{c}17 \\
(0.024)\end{array}$ & experience & $\begin{array}{c}367 \\
(0.026)\end{array}$ & customer & $\begin{array}{c}456 \\
(0.048)\end{array}$ \\
\hline 8 & premium & $\begin{array}{c}11 \\
(0.036)\end{array}$ & business & $\begin{array}{c}9 \\
(0.012)\end{array}$ & excited & $\begin{array}{c}264 \\
(0.019) \\
\end{array}$ & ideal & $\begin{array}{c}243 \\
(0.025) \\
\end{array}$ \\
\hline 9 & TV & $\begin{array}{c}10 \\
(0.032)\end{array}$ & South & $\begin{array}{c}7 \\
(0.010)\end{array}$ & design & $\begin{array}{c}246 \\
(0.017)\end{array}$ & amazing & $\begin{array}{c}212 \\
(0.022)\end{array}$ \\
\hline 10 & show & $\begin{array}{c}7 \\
(0.023)\end{array}$ & best & $\begin{array}{c}6 \\
(0.009)\end{array}$ & inspiration & $\begin{array}{c}60 \\
(0.004)\end{array}$ & fantastic & $\begin{array}{c}132 \\
(0.014)\end{array}$ \\
\hline
\end{tabular}

Note: This result excludes the word of each company name as a keyword.
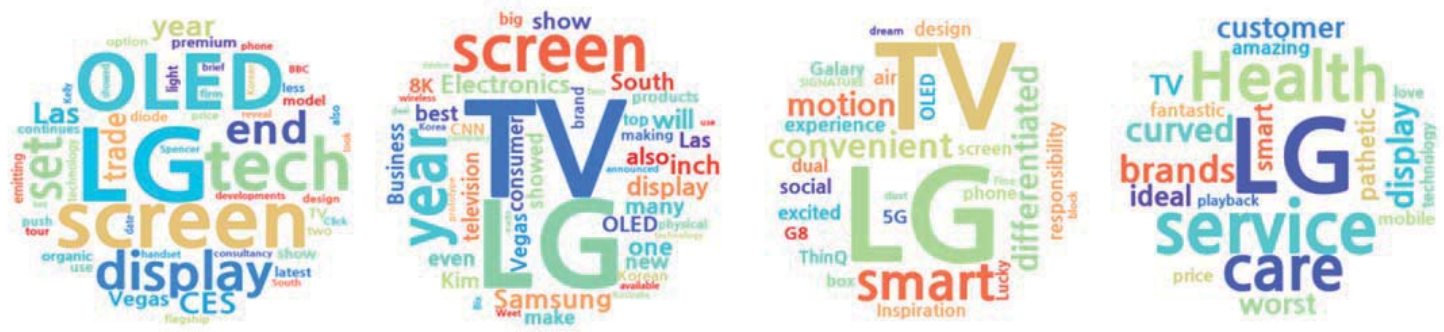

Figure 4: Word Cloud on LG (BBC vs. CNN vs. Facebook vs. Twitter) 
Moreover, the author extracted the association rules based on the support and reliability, and selected the core issues based on the graphical results. Text association analysis was performed using the FT-Growth operator and the Create Association Rules operator. Since the FT-Growth operator calculates only Binomial values, Numerical to Binominal operator is used to change the Numeric property to Binominal value. In the case of regular article analysis, the Min Support parameter value of the FT-Growth operator is set to .95. However, as the number of comments in news articles and particularly social media increases, the number of combinations of words increases a lot. Therefore, the Min value was adjusted to .01 (Han et al., 2017).

Table 6 shows the words with the highest number of concurrent words based on the support and reliability. Samsung is related to 5G, Galaxy, Folding, Innovation, and Best. This is supported by Samsung's new products released recently, foldable phone and $5 \mathrm{G}$ mobile networks. In the case of Hyundai Motor, KIA's parent company is Hyundai, so it has a very high relevance naturally, and it can be seen that the keywords such as various awards, social contribution activities and sports team sponsorship (FC) are related to HMC. OLED TV with LG Electronics' technological power, and LG's Health Care brands including beauty products are all related. This association rule is shown in the following figure.

\section{Conclusions}

\subsection{Discussion and Managerial Implications}

This study explores how mainstream news and social media channels are showing the current events or trends linked with a tremendous shift in control towards individual consumers in business. Those channels are responding to this wave of participatory actions and audience engagement which make it possible to create big data storage for a company. Consequently, this paper shows how a multinational company can use those data to detect key issues, and then make a subsequent strategy or decisionmaking, furthermore, to predict future event. Notably, future prediction in business will be very beneficial in terms of how to launch new product, even design, feature and display which new areas can be touched, what people feel about a business or a product, how to serve customer at the point of customer contacts, and how to change a negative feeling to positive feeling with financial return as well as positive sentiments among stakeholders. Based on those aims and results of this study, the following implications can be obtained.

First, this paper shows the possibility that companies can adopt a two-track strategy to make global decisions through big data. In the traditional news media or journal, it is achievable to establish the global future strategy by deriving the key issues or trends, from the enterprise side, and social media can grasp consumer's tendency, interest issues and sentiments to use it for various marketing strategies including managing corporate reputation. In other words, it is possible to set a strategy developed on product features favored and customer orientation analysis that reflects customer requirements. It can also be used in creating consumer's preferred designs, product category, catalog, shop layout and advertising campaign.

Table 6: The result of Association Analysis for each company

\begin{tabular}{|l|l|}
\hline & The result of Association Rules \\
\hline Samsung & $5 \mathrm{G}$, Galaxy, Folding, Innovation, Best \\
\hline Hyundai Motor Company & KIA, Award, Safety, Recall, FC, Donation \\
\hline LG & OLED, TV, Tech, Health Care, Design \\
\hline
\end{tabular}
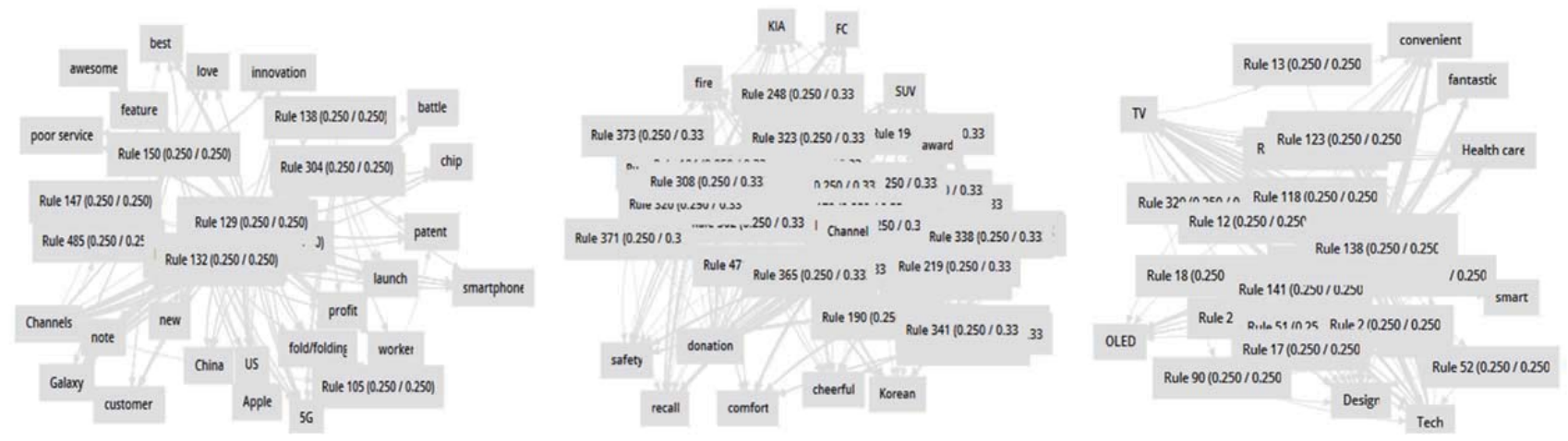

Figure 5: The result of Association Analysis (Samsung vs. Hyundai vs. LG) 
Second, by understanding the characteristics of the Millennium generation, a company can actively and effectively utilize various media formats, especially social media channels to enhance corporate value. It will lead to steady and real-time communication, sympathy formation through the global platforms such as Facebook, YouTube and Twitter contributing to the financial and non-financial performance. Moreover, foreign consumer's awareness or perception and attitude towards Korean MNEs are occasionally an entryway to a broader interest in Korean products and brands. By increasing the awareness of company's name and value, companies can promote foreign consumers' buying behavior on Korean products and services, overall. Also, it can remove any entry barrier and build some opportunities or possibilities for companies which seek to do business internationally not only the main markets but also unfamiliar new markets are accessible. Thus, by estimating foreign consumers' preference or popularity on Korean companies, we can forecast the near future of a company and prepare for subsequent plans to create sustainable competitive advantages.

Lastly, this study gives a valuable data empowered insight to develop a predictive model or forecasting using news and social media data both through text mining technique. It will be devastating tool to find a trend or direction comprehensively on Korean companies in the host countries and build a predictive model for forecasting marketability. From this, Korean multinational corporates can reduce liability of foreignness such as operating and marketing cost and even time as well by not having to detect the trend manually. Moreover, with this prediction, companies can analyze several issues such as a relationship between stock prices and popularity through news and social media, or between profitability or market share and preference through diverse media channels. In addition, it is possible to share a lot of useful information with various, important stakeholders for companies.

\subsection{Limitations and Future Research Directions}

Although this study provides insightful implications to companies and researchers, there are some limitations to be considered for the further research.

First, the model and analysis results proposed in this study are limited to three Korean, global companies. Therefore, it is necessary to diversify the data to a number of companies including small and medium-sized enterprises and even competitors in the future. Comparative study among different sized businesses in evaluating their events and learning from competitors will give us a significant implication. It is also possible to generalize analysis tools through comparative studies.

Second, this study focused on analyzing keywords of only four media channels through text mining. However, by increasing the number of channels, we can develop and compare various future predictive models using several data mining tools including sentiment analysis of texts.

Lastly, it can be seen that combined research between the study of media channels and existing consumer surveys is possible besides existing researches between various media channels. For example, through social media messages from Facebook and Twitter, and traditional consumer confidence indicators (conducted each month in the first half of the month), we can see how the combination of these social media channels is working best to develop marketing or corporate strategy overall and also compare social media psychology. In other words, blended research on media channels in future research shows that companies can conduct consumer research in more diverse and innovative ways.

\section{References}

Amigobulls (2015). How To Predict Stock Market Trends Through Social Media. Retrieved from https://amigobulls.com/articles/predict-stock-markettrends -social-media.

Balan, S. \& Rege, J. (2017). Mining for Social Media: Usage Patterns of Small Businesses. Business Systems Research, 8(1), 43-50.

Barney, J. B., \& Hesterly, W. S. (2013). Strategic management and competitive advantage: Concepts and cases. London, United Kingdom: Pearson.

Becker, K., \& Lee, J. W. (2019). Organizational Usage of Social Media for Corporate Reputation Management. Journal of Asian Finance, Economics and Business, 6(1), 231-240.

Chong, M. Y. (2015). Selecting a key issue through association analysis of real-time search words. Journal of Digital Convergence, 13(12), 161-169.

Delen, D., Walker, G., \& Kadam, A. (2005). Predicting breast cancer survivability: a comparison of three data mining methods. Artificial Intelligence in Medicine, 34(1), 113-127.

Dress, G. G., Lumpkin, G. T., Eisner, A. B., \& McNamara, G. (2014). Strategic Management: Text and Cases. New York, NY: McGraw-Hill Education.

Driscoll, A. (1995). Foreign market entry methods: a mode choice framework. In S. J. Paliwoda \& J. K. Ryans (eds), International marketing reader. New York, NY: Routledge. 
Dunning, J. H. (1981). International Production and Multinational Enterprise. London, England: Allen Unwin.

Dunning, J. H. (1988). The eclectic paradigm of international production: a restatement and some possible extensions. Journal of International Business Studies, 19(1), 1-31.

Gartner (2015). Forecast: Global Business Intelligence Software Market, 2009 2014. Stamford, CT: Gartner Research.

Han, M. M. C., Kim, Y. S., \& Lee, C. K. (2017). Analysis of News Regarding New Southeastern Airport Using Text Mining Techniques. Smart Media Journal, 6(1). 48-54.

Han, J., Kamber, M., \& Pei, J. (2012). Data Mining: Concepts and Techniques. Waltham, MA: Elsevier Inc.

He, W., Tian, X., Chen, Y., \& Chong, D. (2016). Actionable social media competitive analytics for understanding customer experiences. The Journal of Computer Information Systems, 56(2), 45-155.

He, W., Wang, F.K., \& Akula, V. (2017). Managing extracted knowledge from big social media data for business decision making. Journal of Knowledge Management, 21(2), 275-294.

Hill, C. W. L. (2015). International Business: Competing in the Marketplace. New York, NY: McGraw-Hill Education.

Jarid, T.I. (2016). The relationship between the internet, social media, customer preference, and customer loyalty in the hotel industry (Doctoral Thesis). Minneapolis, MN: Capella University.

Lee, C. H., Hur, J., Oh, H. J., Kim, H. J., Ryu, P.M., \& Kim, H. K. (2013). Technology of Issue Detection and Predictive Analysis on Social Big Data.

Lee. H. (2010). Decision to Invest Abroad: The Case of South Korean Multinationals. Pacific Economic Review, 15(2), 281-302.

Lee, J. W., Becker, K., \& Potluri, R. M. (2016). Antecedents of Corporate Adoption of Social Media and the Role of the Technology Acceptance Model in the Path. Journal of Asian Finance, Economics and Business, 3(2), 67-76.

Li, D.C., Chang, C.J., Chen, C.C., \& Chen, W.C. (2012). Forecasting short-term electricity consumption using the adaptive grey-based approach-An Asian case. Forecasting in Management Science, 40(6), 767-773.

Mathupur, P., Black, J.E., Cao, J., Berger, P.D., \& Weinberg, B.D. (2012). The impact of social media usage on consumer buying behavior. Advances in Management, 5(1), 14-22.

Marban O., Mariscal G., \& Segovia J. (2009). Data Mining and Knowledge Discovery in Real Life Applications. Vienna, VN: I-Tech Education and Publishing.

Milanjit K., \& Komal, A. (2018). Role of various data mining techniques in sentimental analysis. International Journal of Advanced Research in Computer Science, 9(3), 178180.

Newman, N. (2009). The rise of social media and its impact on mainstream journalism. Oxford, England: University of Oxford.

Nguyen, X. T. (2015). The impact of social media usage on hi-tech products purchase decision of generation $\mathrm{Y}$ in Vietnam. GE-International Journal of Management Research, 3(10), 123-147.

Nguyen, X. T. (2018). The Impact of Hallyu 4.0 and Social Media on Korean Products Purchase Decision of Generation C in Vietnam. Journal of Asian Finance, Economics and Business. 5(3), 81-93.

Park, Y. E. (2017). Dynamics of Global Distribution after Initial Entry. Journal of Distribution Science, 15(12), 5-19.

Park, Y. E. (2018). The Endless Challenges of KIA Motors for Globalization : A Case Study on Kia in Saudi Arabia. International Journal of Industrial Distribution \& Business, 9(9), 45-52.

Park, Y. E., Chaffar, S., Kim, M. S., \& Ko, H. Y. (2017). Predicting Arab Consumers' Preferences on the Korean Contents Distribution. Journal of Distribution Science, 15(4), 33-40.

Park, Y. E., \& Alenezi M. (2018). Predicting the Popularity of Saudi Multinational Enterprises Using a Data Mining Technique. Journal of Management Information and Decision Sciences, 21(1), 1-14.

Rottwilm, P. (2014). The Future of Journalistic Work: Its Changing Nature and Implications. Oxford, England: University of Oxford.

Sarvestan, S. A., Safavi, A. A., Parandeh, M. N., \& Salehi, M. (2010). Predicting Breast Cancer Survivability using data mining techniques. Paper presented at Software Technology and Engineering (ICSTE) 2nd International Conference (p.227-231).

Shweta, K. (2012). Using data mining techniques for diagnosis and prognosis of cancer disease. International Journal of Computer Science, Engineering and Information Technology, 2(2), 55-66.

Skoler, M. (2009). 2009 Nieman Reports concerning the path and direction of journalism today.

Squires, D. (2016). Social Media's Impact on Journalism.

William, G. N., James, M. M., \& Susan, M. M. (2016). Understanding Business. New York, NY: McGraw-Hill Education.

Zaki, M. J., \& Meira W. (2014). Data Mining and Analysis: Fundamental Concepts and Algorithms. London, LD: Cambridge University Press. 